\title{
Protein Value of Vigna sinensis Seed: Comparison with Soybean-Oil Meal ${ }^{1}$
}

\author{
J. Le Dividich ${ }^{2}$ \\ INTRODUCTION
}

The seeds of legumes are high in crude protein content (20 to 40 percent according to Morrison) (13), providing an important source of protein in human and animal nutrition particularly in tropical regions (2). Their lysine content is generally high ( 5 to $8 \mathrm{~g} / 16 \mathrm{~g} \mathrm{~N})(4,6,7,21)$. However, their protein value is limited; first, by an important sulphur amino acid deficiency $(1.2$ to $3.0 \mathrm{~g} / 16 \mathrm{~g} \mathrm{~N})$; second, by the presence in some of these seeds of thermolabile toxic factors, the nature of which is not too well known $(3,10,14)$.

Among the legumes which can be cultivated in the French West Indies, Vigna sinensis is of special interest because of its dry-seed yield (5), its high protein content (24 percent) and because it is easy to store (17). Its utilization in animal nutrition might bring about a reduction of protein importation.

The present experiment was designed to determine the nutritive value of the proteins of Vigna sinensis as compared with those of soybean-oil meal on the basis of various tests conducted on the growth, digestibility and nitrogen retention of the white rat. The effects of a synthetic DL-methionine supplementation and of the heat treatment (autoclaving) of the seeds were also studied.

\section{MATERIALS AND METHODS}

\section{Vigna sinensis SEED AND ITS COMPOSITION}

The seeds of Vigna sinensis (M.53 breed) were obtained from an experimental sample harvested at the Plant Improvement Department of the Agricultural Research Center (Guadeloupe). Their composition, as determined by chemical analysis, was as follows:

Percent

Dry matter

88.94

Crude protein

24.41

Fat

2.24

1 Manuscript submitted to Editorial Board April 25, 1973.

${ }^{2}$ Chargé de Recherches (I.N.R.A.-France), Petit-Bourg, Guadeloupe (F.W.I.). Thanks are due to Mr. A. Aumaitre and Mr. Y. Henry for their help and assistance in devising the experimental design and for their valuable remarks, and to Mrs. $\mathbf{K}$. Rerat for the translation of the manuscript. 


$\begin{array}{lr} & \text { Percent } \\ \text { Ash } & 3.14 \\ \text { Cellulose (Weende) } & 4.81 \\ \text { N-free extract } & 54.34 \\ \text { Starch }^{\mathrm{a}} & 34.85\end{array}$

ANIMALS, DISTRIBUTION INTO GROUPS, FEEDING METHODS

Forty male rats of the Wistar strain were used in the trial. After a preexperimental period of 1 week post-weaning, during which the animals were fed a commercial diet, 36 rats were divided into 6 equal groups ac-

Table 1.-Percent composition of the diels

\begin{tabular}{lrrrrrr}
\hline \multirow{2}{*}{ Source and ingredients } & \multicolumn{7}{c}{ Diets } \\
\cline { 2 - 7 } & \multicolumn{1}{c}{ I } & II & III & IV & V & VI \\
\hline Raw Vigna sinensis & 59.30 & 59.30 & - & - & - & - \\
Autoclaved Vigna sinensis & & & 59.10 & 59.10 & - & - \\
Soybean-oil meal & - & - & - & - & 31.70 & 31.70 \\
Maize starch & 13.60 & 13.55 & 13.70 & 13.65 & 27.40 & 27.35 \\
Sucrose & 13.60 & 13.55 & 13.70 & 13.65 & 27.40 & 27.35 \\
Mineral mixture & 4.50 & 4.50 & 4.50 & 4.50 & 4.50 & 4.50 \\
Vitamin mixture & 1.00 & 1.00 & 1.00 & 1.00 & 1.00 & 1.00 \\
Corn oil (+ AD vitamins) & 8.00 & 8.00 & 8.00 & 8.00 & 8.00 & 8.00 \\
DL-methionine & - & .15 & - & .15 & - & .10 \\
& & & & & & \\
Crude protein, percent & 13.93 & 13.90 & 14.10 & 14.13 & 14.12 & 14.12 \\
Calculated methionine + & .32 & .47 & .32 & .47 & .46 & .56 \\
$\quad$ cystine, percent & & & & & & .98 \\
Calculated lysine, per- & 1.11 & 1.11 & 1.11 & 1.11 & .98 & .98 \\
$\quad$ cent & & & & & & \\
\hline
\end{tabular}

1 According to Osborne and Mendel.

2 Calculation made from the data of Busson (4) and Evans (6) with respect to the Vigna sinensis diets, and of Pion (16) with respect to the soybean-oil meal diets.

cording to weight. The weight gain was recorded during the pre-experimental period and 4 rats were slaughtered for initial body $\mathrm{N}$ content.

The animals, caged separately, were fed ad libitum one of the diets reported in table 1 . The trial lasted 12 days. Net food intake was individually recorded. From the seventh to the eleventh day, feces of four rats per group were collected, weighed and kept frozen at $-15^{\circ} \mathrm{C}$ until analyzed.

At the end of the trial all the rats were weighed, slaughtered, pooled together (per group) for final body $\mathrm{N}$ content and kept frozen at $-15^{\circ} \mathrm{C}$ until analyzed.

Enzymatic analysis by means of amyloglucosidase. 


\section{NATURE OF THE DIETS}

The Vigna sinensis seed and the soybean-oil meal were the only nitrogen sources in the diets, and they supplied about 14 percent of protein (table 1), which corresponds to a slightly suboptimum level for growing rats.

The meal was steam-cooked by autoclaving for 15 minutes at $121^{\circ} \mathrm{C}$ (6). The diets based on Vigna sinensis and soybean-oil meal were respectively supplemented by 0.15 and 0.10 percent of synthetic DL-methionine.

CRITeria USED fOR DeterminiNg THE BIOLOGICAL VALUE OF THE PROTEINS

The criteria studied were growth rate, food efficiency, apparent digestibility of nitrogen, protein efficiency ratio (PER) and net protein utilization (NPU). The criteria were defined as follows:

$$
\text { Food efficiency: } \frac{\text { weight gain }(\mathrm{g})}{\text { dry matter intake (g) }}
$$

Apparent digestive utilization coefficient of the protein (nitrogen):

$$
\frac{N \text { ingested }(g)-\text { faecal } N(g) \times 100}{N \text { ingested }(g)}
$$

Protein efficiency ratio (PER):

$$
\frac{\text { weight gain }(\mathrm{g})}{\text { protein intake }(\mathrm{g})}
$$

Net protein utilization (NPU):

$$
\frac{\text { final body } \mathrm{N}-\text { initial body } \mathrm{N}}{\mathrm{N} \text { intake }(\mathrm{g})} \times 100
$$

The statistical analysis of the results was carried out according to Snedecor (21), with comparison of the means by the Duncan multiple range test.

\section{RESULTS}

\section{GROWTH AND FOOD INTAKE}

The results on the growth and food intake of the animals during the whole experimental period are reported in table 2 .

In the Vigna sinensis diets, the heat treatment and DL-methionine supplementation significantly $(P=0.01)$ improved the growth rate and daily food intake of the animals. There also was an increase of food efficiency of the diets and of PER and NPU. The effects of autoclaving and 
DL-methionine supplementation were additive and maximum performances were obtained with autoclaved supplemented diets.

In the diets based on soybean-oil meal, DL-methionine supplementation significantly improved the growth rate of the animals, food efficiency, PER, and NPU.

Moreover, autoclaving and DL-methionine supplementation of Vigna sinensis resulted in growth performances, food efficiency, and PER, which were practically identical to those obtained with non supplemented soybean-oil meal.

TABLE 2.-Growlh performances, food intake, food efficiency, and protein efficiency ratio of the diets

\begin{tabular}{|c|c|c|c|c|c|c|}
\hline \multirow{3}{*}{ Item } & \multicolumn{6}{|c|}{ Source of protein } \\
\hline & \multicolumn{4}{|c|}{ Vigna sinensis seed diets } & \multicolumn{2}{|c|}{$\begin{array}{c}\text { Soybean-oil meal } \\
\text { diets }\end{array}$} \\
\hline & I & II & III & IV & $\mathbf{v}$ & VI \\
\hline $\begin{array}{l}\text { Mean daily gain } \\
\text { (g/day) }\end{array}$ & $0.12^{2} 1$ & $2.08^{b}$ & $2.86^{\mathrm{c}}$ & $4.27^{d}$ & $4.25^{d}$ & $5.12^{\circ}$ \\
\hline $\begin{array}{l}\text { Ingested DM } \\
\text { (g/day) }\end{array}$ & $7.87^{a}$ & $11.80^{\mathrm{b}}$ & $11.74^{b}$ & $12.72^{\mathrm{bo}}$ & $12.93^{\mathrm{bo}}$ & $13.55^{\circ}$ \\
\hline Food efficiency & $.02^{a}$ & $.18^{b}$ & $.24^{\circ}$ & $.30^{\mathrm{d}}$ & $.33^{d}$ & $.38^{\circ}$ \\
\hline PER $^{2}$ & $.10^{\mathrm{a}}$ & $1.17^{b}$ & $1.65^{\circ}$ & $2.25^{\mathrm{d}}$ & $2.18 \mathrm{~d}$ & $2.52^{\circ}$ \\
\hline $\mathrm{N}$ retained (mg/day) & 23 & 83 & 87 & 139 & 158 & 182 \\
\hline NPU $^{3}$ & 12.30 & 29.87 & 30.66 & 45.50 & 49.72 & 54.78 \\
\hline
\end{tabular}

1 Data not followed by the same letter are statistically different at the 1-percent level.

2 Protein efficiency ratio.

${ }^{3}$ Net protein utilization.

\section{DIGESTIBILITY COEFFICIENTS}

Because of the lack of response to DL-methionine supplementation insofar as the apparent digestibility of the diet, the corresponding information has not been presented (table 3).

Autoclaving increased ( +2 per cent, $P=0.05$ ) the apparent digestibility of the organic matter in the diets based on Vigna sinensis and considerably increased that of the protein $(+12$ percent, $\mathrm{P}=0.01$ ).

The apparent digestibility of the organic matter and of the protein of the diets based on soybean-oil meal was always significantly higher $(\mathrm{P}=$ 0.01) than that corresponding to the diets based on Vigna sinensis.

\section{DISCUSSION}

The increase in the growth rate attributed to DL-methionine supplementation of Vigna sinensis or soybean-oil meal is in aggreement with the 
observations made by Finks (8) and Sherwood (20). According to the analysis it is true, indeed, that the sulphur amino acids are the limiting factor of legume seed protein $(6,15,22)$. Under our experimental conditions, the diets based on non-supplemented Vigna sinensis seed and soybean-oil meal show a sulphur amino acid deficiency of 40 and 10 percent, respectively, in comparison with the sulphur amino acid requirements of the rat as defined by Rerat (18). The DL-methionine supplementation resulted in an improvement of the growth rate in connection with an increase of the food intake, and especially of the food and protein efficiency.

Autoclaving of Vigna sinensis improves average daily gain, as well as nitrogen digestibility and NPU, as reported by Borchers (3), Evans (6), Owusu-Dompeh (15), and Mescle (12). The positive effect of this treatment may be attributed to the destruction of thermolabile proteolytic substances (3). This result is in line with those of Sevilla-Eusebio (19) and

TABLE 3.-Digestive utilization of organic matter and of nitrogen

\begin{tabular}{llcc}
\hline & \multicolumn{3}{c}{ Source of protein } \\
\cline { 2 - 3 } Digestive utilization coefficients of - & \multicolumn{2}{c}{ Vigna sinensis } & \multirow{2}{*}{ Soybean-oil meal } \\
\cline { 2 - 3 } & Raw & Autoclaved & \\
\hline Organic matter & $86.9^{\mathrm{a} 1}$ & $88.5^{\mathrm{b}}$ & $93.8^{\mathrm{c}}$ \\
Nitrogen & $70.7^{\mathrm{A}}$ & $80.1^{\mathrm{B}}$ & $87.3^{\mathrm{C}}$ \\
\hline
\end{tabular}

1 Data not followed by the same letter are statistically different at the 5-percent (abc) or 1-percent (ABC) level.

Le Dividich (9) with pigs, and with those of Maust (11) with growing chickens fed diets based on Vigna sinensis seed. It has been mentioned that it is necessary to limit the treatment duration $(1,22)$ and temperature (23) in another connection, according to Sherwood (20), because the effect of autoclaving may depend on the variety used.

In conclusion, it appears that the nutritive value of the proteins of Vigna sinensis seed is limited on one hand by a sulphur amino acid deficiency and, on the other by the presence of proteolytic substances the deleterious effects of which may be destroyed by heat. It seems, therefore, that Vigna sinensis seed autoclaved at $121^{\circ} \mathrm{C}$ for 15 minutes and correctly supplemented by DL-methionine has a nutritive value almost similar to that of soybean-oil meal.

\section{SUMMARY}

The protein value of raw and heated Vigna sinensis seed (M. 53 breed) was compared with that of soybean-oil meal when fed to male rats at a 14-percent protein level. 
Autoclaving the seed at $121^{\circ} \mathrm{C}$ for 15 minutes and adding 0.15 percent of synthetic DL-methionine to the diets improved the growth rate, food efficiency, and protein efficiency ratio. Besides, autoclaving the seed increased $\mathrm{N}$ digestibility and $\mathrm{N}$ retention.

When autoclaved and supplemented by synthetic DL-methionine, the protein value of Vigna sinensis seed was practically identical to that of non supplemented soybean-oil meal.

\section{RESUMEN}

Se comparó el valor proteínico de la semilla de Vigna sinensis (raza M. 53) fresca y calentada con el de la harina de soya, ambas con un nivel de 14 por ciento de proteína, en pruebas de alimentación con ratos (macho de la rata).

Al calentarse la semilla en un autoclave a $121^{\circ} \mathrm{C}$ por 15 minutos y añadírsele 0.15 por ciento de DL-metionina sintética a las dietas se mejoró el ritmo de crecimiento y la tasa de eficiencia del alimento y de la proteína. Además, el calentamiento de la semilla aumentó la digestibilidad y la retención del $\mathrm{N}$.

Cuando se calentó la semilla de Vigna sinensis y se suplementó con DL-metionina sintética su valor proteínico fue casi similar al de la harina de soya sin suplemento.

\section{LITERATURE CITED}

1. Adrian, J., Etude de la valeur protidique de trois légumineuses domestiques africaines (Voandzou, Dolique et Niébé) Ann. Nutr. Anim. 17: 1-18, 1963.

2. Aikroyd, W. R., and Doughty, J., Legumes in human nutrition, Nutritional Studies No. 19, Rome, Italy, FAO, 1964.

3. Borchers, R., and Ackerson, C. W., The nutritive value of legumes seeds. Effect of autoclaving and the trypsin inhibitor test for 17 species, J. Nutr. 41: 339-45, 1959.

4. Busson, F., Plantes alimentaires de l'Ouest Africain, thèse Doc. Fac. Sci. Marseille, France, 1965.

5. De Rieux, M., Résultats d'essais préliminaires à l'étude de deux légumineuses vivrières, Proc. VIIth Annual Meeting C.F.C.S., Martinique, Guadeloupe, 164-172, 1969.

6. Evans, R. J., and Bandemer Selmail, S. L., Nutritional value of legume seeds proteins, J. Agr. Food Chem. 15: 439-443, 1967.

7. Everson, G., and Heckert, A., The biological value of some leguminous sources of protein, J. Amer. Diet. Assoc. 20: 81-4, 1944.

8. Finks, A. J., Jones, D. B., and Johns, C. C., The role of cystine in the dietary properties of the proteins of the cow-pea "Vigna sinensis", and of the field-pea "Pisum sativum", J. Biol. Chem. 52: 403-10, 1922.

9. Le Dividich, J., Unpublished data, 1972.

10. Liener, I. E., and Pallansch, M. J., Toxic factors in edible legumes and their elimination, Amer. J. Clin. Nutr. II: 281-5, 1962.

11. Maust, L. E., Scott, M. L., and Pond, W. G., The metabolizable energy of rice bran, cassava flour and blackeyed cowpeas for growing chickens, Poultry Sci. 54: 1,397-401, 1972.

12. Mescle, J. P., and Pion, R., Participation à l'étude de la valeur nutritive des protéines du Vigna sinensis (unpublished data), 1971.

13. Morrisson, F. B., Feeds and feeding, 22nd ed, Morrisson Publishing Co. Ithaca, New York, 1967. 
14. Osborne, T. B., and Mendel, L. B., The use of soybean as food, J. Biol. Chem. 32: $369,1917$.

15. Owusu-Dompeh, K., Christensen, D. A., and Owen, B. D., Nutritive value of some Ghanaian feedstuffs, Can. J. Anim. Sci. 50: 1-14, 1970.

16. Pion, R., De Belsunce C., and Fauconneau, G., Composition en acides aminés de quelques aliments, Ann. Biol. Anim. Bioch. Bioph. 3: (No. H.S.): 11-18, 1963.

17. Pointel, J. G., Contribution à la conservation du Niébé, Agron. Trop. 10: 925-32, 1967.

18. Rerat, A., and Henry Y., Détermination des besoins en acides aminés soufrés chez le rat blanc en croissance, Ann. Biol. Anim. Bioch. Bioph. 5: 469-81, 1965.

19. Sevilla-Eusebio, J., Gonzales, R. R., Eusebio, J. A., and Alcantara, P. F., Effect of heat on the biological value of Munggo, Paayap, Tapilan and Kaydos beans, Philippine Agriculturist 52: 216-32, 1968.

20. Sherwood, F. W., Effect of cooking and of methionine supplementation on the growth promoting property of cow-pea (Vigna sinensis) protein, J. Nutr. 52: 199-208, 1954.

21. Snedecor, G., Statistical methods, 5th ed, The Iowa State University Press, Ames, Iowa, 1956.

22. Tannous, R. I., and Ullah, M., Effects of autoclaving on nutritional factors in legume seeds, Trop. Agr. Trin. 46: 123-9, 1969.

23. Vermorel, M., Personal communication, 1973. 